\title{
音響性聴覚障害と “Hidden hearing loss”
}

\author{
自治医科大学附属さいたま医療センター耳鼻咽喉科
}

吉田尚弘

音響性聴覚障害は，強大音曝露により感音難聴を来す 疾患である。世界保健機関（World Health Organization： WHO）は，世界の若者（12～35歳）の半数近くに当た る11億人が音響性聴覚障害を生ずる危険性があると報告 している，産業化による環境音の増加，さらにはデジタ ル音楽プレーヤー, スマートフォンの普及は強大音に曝 露される機会を増加させている. 2019年, WHO と国際 電気通信連合（International Telecommunication Union： ITU）は，音楽再生機器の使用に関する国際基準を公表 した。安全利用の目安を大人で音量 $80 \mathrm{~dB}$ ，子供で $75 \mathrm{~dB}$ を 1 週間に40時間までとし，機器にどの音量をどのくら い聴いたかを明示する機能を付けるべきだと提言してい る。音響性聴覚障害は予防が最も重要かつ有効であり, 日本耳鼻咽喉科学会は “Hear well. Enjoy Life”, 米国 NIDCD (National Institute on Deafness and Other Communication Disorders) でも “It’s a Noisy Planet.”キャ ンペーンを展開し, 強大音曝露回避の重要性に関する啓 発活動を行っている.

\section{1．音響性聴覚障害における PTS と TTS}

音響性聴覚障害には，ディスコ，コンサート，射撃な ど強大音曝露による急性音響性感音難聴と，長時間にわ たる音響曝露により慢性に進行する騒音性難聴に大きく 分けられる．急性音響性感音難聴には，聴力回復が困難 な永久的閾值上昇 (Noise-induced permanent threshold shift：NIPTS）と一過性で聴力が回復する一過性閾值上 昇 (Noise-induced temporary threshold shift: NITTS) があり, 強大音曝露の音圧, 曝露時間によって決まるが 易受傷性には個人差がある。臨床上問題となるのは NIPTS と考えられていたが，近年マウスの実験から後 で述べるように NITTS でも蝸牛, 内耳の機能低下を引 き起こしていることが明らかとなった ${ }^{1)}$.

一方で慢性の音響性聴覚障害である騒音性難聴初期 は, 高音域 $4,000 \mathrm{~Hz}$ 付近の $\operatorname{dip}$ 型の難聴を呈する。そ の機序としては, 外耳道共鳴説, リンパの渦流説, 血管 血流説などが提唱されているが，この周波数領域が解剖
学的に固有蝸牛動脈と前庭蝸牛動脈螖牛枝の吻合部に相 当し血流障害による有毛細胞障害が起こりやすいのでは ないかとする説を支持する意見が多い，自覚症状に乏し い点から，標準純音検査ではじめて指摘されることもあ るが，外傷や突発性にも高音域の dip が生ずることがあ るため病歴聴取を含めて診断は丁寧かつ慎重に行う必要 がある。

\section{2.コルチ器における音響曝露の易受傷性}

音響曝露によって (1) mechanical (2) metabolic な機 序が相まって内耳障害が生ずる。螖牛の中で, 内有毛細 胞, 外有毛細胞のあるコルチ器が最も音響曝露の影響を 受け易い. 求心性神経（らせん神経節細胞）と主として シナプスを作る内有毛細胞とフィードバックをかける遠 心性神経が主として分布する外有毛細胞とが協調して音 受容に関与する．プレスチンを有する外有毛細胞の伸縮 能により，小さな音では特に基底板の振動は増幅されダ イナミックレンジが大きくなる，外有毛細胞は内有毛細 胞よりも音響曝露により障害を受けやすい. 形態学的に は, 強大音曝露により有毛細胞の stereocilia が最も損傷 されやすく, 外有毛細胞の stereocilia が消失し外有毛細 胞による増幅機構が消失することにより約 $40 \mathrm{~dB}$ の閾値 上昇を生ずる。したがって，音響曝露後 $40 \mathrm{~dB}$ 以上の聴 力閾值上昇がある場合，外有毛細胞のみならず，内有毛 細胞あるいは求心性神経のシナプスも何らかの障害を受 けていると考えられる。

\section{Hidden hearing loss}

従来のネコの行動実験の研究結果から, 求心性（螖 牛) 神経の約 $80 \%$ 以上の機能が消失しないと聴力は低下 しないことが報告されていだ2.

近年，マウスの実験系で一過性には聴力閾值の上昇を 起こすがその後回復する強大音曝露（NITTS）条件下 で, 内有毛細胞と求心性神経とのシナプスの变化につい て共焦点顕微鏡を用いて詳細に研究されている ${ }^{3)}$. 音響 曝露一定時間後には，純音を用いた聴力閾值測定では聴 


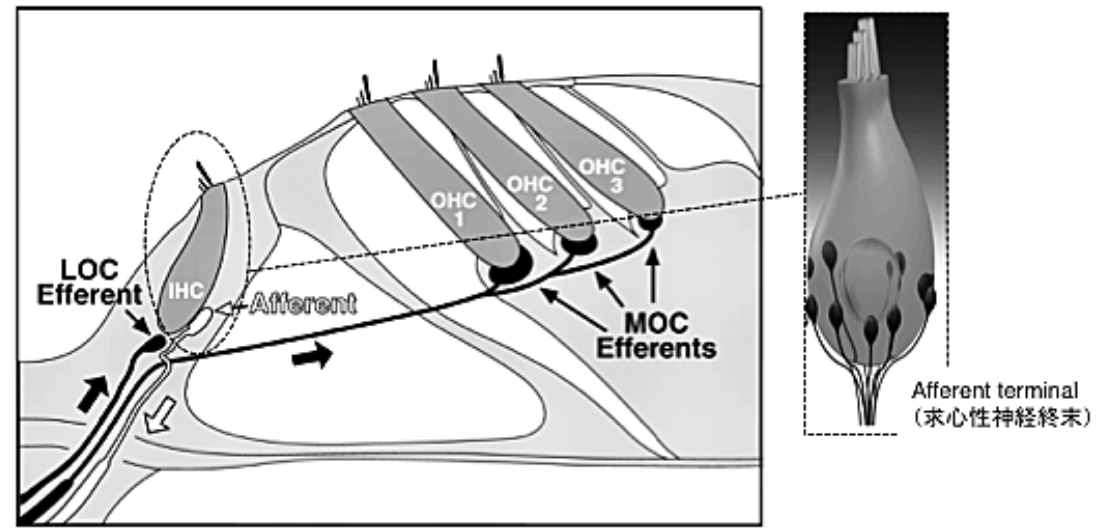

図 内有毛細胞 (IHC), 外有毛細胞 $(\mathrm{OHC})$ と求心性神経 (Afferent), 遠心性神経 (LOC, MOC) の分布

カレベルが回復していた。 しかし，組織学的に，らせん 神経節細胞の消失, stereociliaの障害などは見られない ものの，内有毛細胞の神経伝達物質放出にかかわるシナ プスリボン，らせん神経節細胞とのシナプスの約 $50 \%$ は 機能しなくなっていた，NITTSにより，内有毛細胞と 求心性神経とのシナプス機能の障害 cochlear synaptopathy が生じていることが明らかとなり，また約 $80 \%$ 程度 のシナプスが障害されるまでは聴力閾值は正常範囲を 示すことから，この病態をいわゆる“Hidden hearing loss”と表現されている ${ }^{4)}$ とトでも同様に，このよう な “Hidden hearing loss” は音響性聴覚障害や加齢性難 聴などで生じていると考えられている.

さらに，マウスでは，若年期の音響曝露による NITTS の既往は，その後の加齢による聴力低下が大きいことも 示されている ${ }^{5)}$. 音響曝露により標準純音聴力検査では 正常範囲内に回復したとしても，内有毛細胞のシナプス 機能は何らかの障害が生じており，音響曝露機会の反復 はシナプス機能障害, その後の加齢性難聴の進行を増悪 させる可能性が高い

静かな環境で行う純音聴力検査では比較的少ない求心 性神経でも音の認識は可能である。一方で, 語音聴取や さらに騒音下などでの会話聴取などでは多くの求心性神 経からの情報が必要となる。純音聴力検査では正常範囲 の聴力にもかかわらず語音明瞭度が低い場合，後迷路性 障害として中枢性の要因・病態が考えられていたが，そ れに加えて “Hidden hearing loss”による病態も含まれ ている可能性がある。
4.おわりに

音響性聴覚障害はその多くが予防可能である。一方 で，強大音に対する易受傷性には個人差がある。純音聴 力検查で正常でも，螖牛機能が低下している“Hidden hearing loss”の病態を認識する必要がある。ママウスで は高音圧の音刺激での ABR I 波が診断に有効との報告 があるがヒトに適応することは難しい．高音域の聴力検 査，螖電図，騒音下など条件を変えた下での語音明瞭度 検査などの研究をすすめ, “Hidden hearing loss”を診 断することは今後重要となる.

\section{参考文献}

1) Kujawa SG, Liberman MC: Adding insult to injury : cochlear nerve degeneration after "temporary" noise-induced hearing loss. J Neurosci 2009; 29 : 14077-14085.

2) Schuknecht HF, Woellner RC:An experimental and clinical study of deafness from lesions of the cochlear nerve. J Laryngol Otol 1955; 69 : 75-97.

3) Kujawa SG, Liberman MC: Synaptopathy in the noiseexposed and aging cochlea: Primary neural degeneration in acquired sensorineural hearing loss. Hear Res 2015 ; 330 : 191-199.

4) Liberman MC: Noise-induced and age-related hearing loss: new perspectives and potential therapies. F1000 Res 2017 Jun $16 ; 6: 927$.

5) Fernandez KA, Jeffers PW, Lall K, et al: Aging after noise exposure : acceleration of cochlear synaptopathy in “recovered” ears. J Neurosci 2015 ; 35 : 7509-7520.

連絡先７330-8503 さいたま市大宮区天沼町 1-847

自治医科大学附属さいたま医療センター耳鼻咽喉科

吉田尚弘 